\title{
The Effect of Leadership Style and Compensation on Company Performance with Job Satisfaction as an Intervening Variables in PT Arminareka Perdana
}

Norman Maulana*, Wagiarto Hoesin, Wachyudi

Universitas Krisnadwipayana, Campus Unkris Jatiwaringin PO BOX 7774/Jat CM Jakarta 13077, Indonesia

\begin{tabular}{|c|c|}
\hline $\begin{array}{c}\text { Article History } \\
\text { Received: } 05.10 .2020 \\
\text { Accepted: } 20.10 .2020 \\
\text { Published: } 26.10 .2020 \\
\text { Journal homepage: } \\
\text { https://www.easpublisher.com/easjebm }\end{array}$ & $\begin{array}{l}\text { Abstract: This study aims to determine the effect of leadership style and compensation } \\
\text { on company performance with job satisfaction as intervening variables. The research was } \\
\text { conducted at PT Arminareka Perdana. The research sample was } 70 \text { respondents. The } \\
\text { sampling technique used random sampling techniques and data analysis techniques used } \\
\text { path analysis. The results showed that the leadership style variables affect company } \\
\text { performance. The compensation variable affects company performance. Job satisfaction } \\
\text { variables affect company performance. The influence of leadership style on company } \\
\text { performance through employee job satisfaction is } 0.216 \text {. In this case, the direct effect is } \\
\text { greater than the indirect effect, so it can be said that the job satisfaction variable is not } \\
\text { intervening. The effect of compensation on employee performance through job } \\
\text { satisfaction is } 0.253 \text {. In this case, the direct effect is greater than the indirect effect, so it } \\
\text { can be said that the job satisfaction variable is not intervening. } \\
\text { Keywords: Leadership style, compensation, job satisfaction company performance. }\end{array}$ \\
\hline pyright $(C) 2$ & $\begin{array}{l}\text { article distributed unc } \\
\text { istribution, and repro }\end{array}$ \\
\hline
\end{tabular}

\section{INTRODUCTION}

The development of increasingly advanced science and technology has led to the emergence of various innovations or discoveries that can facilitate and facilitate company business activities. The developments that occur have an impact on companies, both companies engaged in services and companies engaged in non-service sectors. This has resulted in more intense business competition among business actors in these fields. To be able to survive and continue their business, companies need to improve themselves and start considering all aspects related to the company's operations. Companies as business actors must be able to adapt to existing developments.

Seeing the current situation and conditions, companies continue to improve and improve themselves to adapt to existing developments. To be able to compete with other companies, one important aspect that needs serious attention from companies, both service, and non-service companies, is the aspect of human resources. The survival and development of a company do not only depend on the merits of the company's financial management, service, promotion, and marketing as well as the level of quality of its products but is also determined by its success in managing human resources. Human resources are considered an important resource for the organization because, without quality human resources, the organization will not be able to survive in the competition.

Good human resources will encourage the company to progress and develop. The advanced and sophisticated equipment owned by the company will not be useful if it is not supported by good human resources. Human resources are the most important asset in a company and maintain and develop the company in various demands of society and era. Good performance of resources is important for the survival of the company. If a company wants to grow rapidly, it must have human resources capable of performing well.

Managing human resources in an organization/company is not easy because it involves various elements, namely employees, leaders, and the system itself. The combination of these three things is expected to be able to create a conducive work environment so that both employees and leaders can carry out their jobs optimally. Several ways can be taken to create or form good human resources and following company needs, namely by recruiting qualified and skilled workers and by improving the quality of the workforce that is owned, namely through training and by creating a good corporate climate. Good leadership style and good and fair compensation, which 
will affect employee satisfaction at work and in the end will affect company performance to increase company productivity.

Good or bad productivity of the company cannot be separated from the performance of the companies in the company. According to Rivai \& Basri, [1] company performance is something that is produced by a company in a certain period concerning the set standards. The company's performance is something that needs to be taken seriously by the company because the performance with various aspects in it will have a direct impact on the company's overall performance. It often happens that company performance decreases due to inconvenience at work, low wages, inadequate ability or expertise and dissatisfaction at work. Employee job satisfaction must be taken seriously by every company.

In an organization, be it a business organization or a non-business organization, leadership becomes an important factor that determines the continuity or sustainability of the organization. The role of leadership is very strategic and important in an organization as one of the determinants of success in achieving the mission, vision and goals of an organization. Leaders must be able to organize and create a conducive work atmosphere where the existing work atmosphere makes employees feel comfortable and fosters a sense of discipline to complete work.

Leadership that is needed is one that can direct and use human resources available optimally so that employees will feel comfortable at work and will affect job satisfaction and performance of the employees concerned. A leader will be able to adjust to the circumstances. The leadership style that is applied will be adjusted to the needs, situations and conditions that occur in the company. According to Fiedler in Thoha [2], the leadership style combined with the situation will be able to determine the success of work implementation. Performance and job satisfaction will also be affected by the compensation received. Compensation according to Nawawi [3] is an award or reward for workers who have contributed to realizing their goals, through activities called work. The compensation received by employees will provide more encouragement to work.

The existence of compensation in the form of bonuses, prizes and awards will also have a positive impact on employees. Employees will feel motivated and enthusiastic in completing the assigned tasks and employee motivation will emerge. There are several purposes for providing compensation, among others, as a collaboration between the company and employees, as a means to increase employee morale and motivation, as a company strategy to retain quality employees or employees, as a reward by the company for employees and so on.
PT. Arminareka Perdana is one of the companies that organize Umrah and Hajj plus trips that see an opportunity to provide opportunities for the community of pilgrims and Umrah pilgrims to earn more through references to the company. Through PT. Lima Utama Sukses which is the marketing agency of PT. Arminareka Perdana, the congregation is allowed to perform Hajj or Umrah as well as earn income by referring the companies that carry out the Hajj and Umrah pilgrimages to their colleagues or colleagues. If pilgrims can refer at least 3 (three) prospective congregations to attend the Hajj or Umrah pilgrimage to PT. Lima Utama Sukses will get a fairly large fee according to the calculation set by the company. So it can be said that PT. Lima Utama Sukses is not only looking for a profit in running its business but also paying attention to the welfare of the congregation who participates in the Hajj and Umrah pilgrimage.

It is also important and needs to be taken seriously by companies in increasing productivity is the company's performance. Company performance influences productivity. In practice, many Umrah and Hajj travel companies are less able to compete with other companies due to the company's low performance.

The company requires employees to work well, following the rules and targets set by the company, but the company does not pay attention to aspects that affect performance such as the level of job satisfaction felt by employees, leadership style and compensation. Lack of management attention to these aspects causes the employee's performance to be less than optimal and as a result, the overall company performance will decline.

Most of the Umrah and Hajj Plus travel companies still apply a leadership style that is authoritarian and directive. Employee participation in decision-making and policymaking is still minimal. This can be seen from the fact that employees are rarely included in meetings so that complaints that are felt and suggestions from employees are not properly channeled. The compensation system in place is also limited to basic salaries and allowances. The management has not implemented a system of giving prizes, bonuses and awards for outstanding employees. This results in employees being less motivated to perform and work well, employees only work to fulfill their obligations to the company.

The leadership style and compensation system imposed by company management are thought to have caused the level of employee job satisfaction that has not been optimal. Many employees are not satisfied with the existing leadership and compensation. Low employee job satisfaction will cause employees to feel uncomfortable at work, high absenteeism levels, many employees resigning, decreased work performance which in turn will decrease employee performance. The 
low employee performance resulted in the company being unable to develop business and compete optimally.

\section{LITERATURE REVIEW Leadership Style}

Leadership style is the basis for classifying the type of leadership. Style means attitude, movement, behavior, beautiful attitude, good gestures, strength, ability to do good. And leadership style is behavior and strategy, as a result of a combination of philosophies, skills, traits, attitudes, which are often applied by a leader when he tries to influence the performance of his subordinates.

According to Hasibuan [4] states that leadership style is the way a leader influences the behavior of subordinates which aims to encourage job passion, job satisfaction and high employee productivity, to achieve maximum organizational goals. Meanwhile, according to Heidjrachman and Husnan [5] states that the leadership style represents the philosophy, skills and attitudes of leaders in politics. Leadership style is a pattern of behavior designed to integrate organizational goals with individual goals to achieve certain goals.

Thoha [2] suggests that leadership style is a behavior norm that a person uses when that person tries to influence the behavior of others as he sees it. Herujito [6] defines leadership style as follows leadership style, not talent, therefore leadership style learned and practiced in its application must be following the situation at hand.

Leadership style is the ability to influence other people, subordinates or groups, the ability to direct the behavior of subordinates or groups by having special abilities or expertise in the area desired by the group, to achieve organizational or group goals. Every leader has different behavior in leading his followers, the behavior of these leaders is called a leadership style. Leadership style is a way for leaders to influence their subordinates which are expressed in the form of behavior or personality patterns. A leader is someone who has a program and who behaves jointly with group members using a certain way or style, so that leadership has a role as a dynamic force that encourages, motivates, and coordinates the company in achieving predetermined goals.

Based on some of the definitions of leadership style above, it can be concluded that leadership style is a person's ability to direct, influence, encourage and control other people or subordinates to be able to do something on their awareness and voluntarily in achieving a certain goal.

\section{Compensation}

Compensation is an important function in human resource management (HRM). Because compensation is one of the most sensitive aspects in a working relationship. Cases that occur in an employment relationship contain compensation issues and various related aspects, such as benefits, compensation increases, compensation structures and compensation scales.

Compensation includes direct cash payments, indirect payments in the form of employee benefits, and incentives to motivate employees to work hard to achieve higher productivity. If managed properly, this compensation can help the company to achieve higher productivity for its employees. Conversely, if without sufficient compensation, it is very possible for employees to leave the company and to make replacement is not easy. According to Soekidjo [7] states that compensation is calculated based on job evaluation, the calculation of compensation based on job evaluation is intended to obtain the compensation that is close to worth and fairness (equity).

Compensation can be given in various forms, such as: in the form of money giving, in the form of material giving, and in the form of providing career opportunities, according to Singodimedjo [8], arguing that: "Giving money directly, such as salaries, allowances and incentives. Salary is compensation given to an employee periodically (usually once a month). Employees who receive salaries generally have become permanent employees who have passed the probationary period (prospective employees). Allowances are compensation provided by the organization to its employees because these employees are deemed to have participated. For example transport allowance, housing allowance and so on ".

Wibowo, [9] argues that compensation is a contra performance against the use of personnel or services that have been provided by employees in carrying out activities. According to Handoko [10] states compensation is anything that employees receive in return for their work. Compensation can be given in various forms, such as: in the form of materials, and in the form of providing facilities, and in the form of providing career opportunities.

\section{Job Satisfaction}

The term satisfaction refers to the general attitude of an individual towards his job, someone with a high level of satisfaction shows a positive attitude towards work. Satisfaction has turned out to be a very popular topic among industrial and management psychologists.

Satisfaction is a matter that is quite interesting and important because it has proven to be of great benefit both for the interests of individuals, industry and 
society. For individuals, research into the causes and sources of gratification allows efforts to increase the happiness of their life. For industry, research on satisfaction is carried out to increase production and reduce costs by improving employee attitudes and behavior. Furthermore, society will certainly enjoy the maximum capacity yield from the industry and the increase in human value in the context of work.

There are various definitions or limitations of satisfaction. First, the notion that contains satisfaction as a complex emotional reaction, second, the notion that satisfaction is an employee's attitude towards work related to work situations. According to Handoko [10], argues that job satisfaction is a pleasant or unpleasant emotional state in which employees view their work. Satisfaction reflects a person's feelings about his job. This is evident in the positive attitude of employees towards work and everything they face in their work environment.

Satisfaction usually refers to pleasant things and sometimes also too unpleasant things. Satisfaction is dynamic, which means that it continues to grow. Therefore, satisfaction is relative. When a person has achieved satisfaction, then there is also a demand for satisfaction of a higher quality and quantity. Also, in line with this statement, Gibson, et al. [11] states that satisfaction tends to contain positive and negative aspects of individual reactions towards future tasks.

\section{Company Performance}

Performance is a description of the extent to which an organization has succeeded or failed in carrying out its main duties and functions to realize its goals, objectives, vision and mission. In other words, performance is an achievement that can be achieved by the organization in a certain period. If an organization or company wants to progress or develop, it is required to have qualified employees. Qualified employees are employees whose performance can meet the targets or targets set by the company. To get employees who have good performance, performance implementation is needed.

Company performance is something that is produced by a company in a certain period by referring to the established standards. The company's performance should be a measurable result and describe the empirical conditions of a company from various agreed sizes. So, it can be concluded that performance is the ability, effort and opportunity of personnel, teams or organizational units in carrying out their duties to realize the strategic goals that have been set. The success of strategic achievement which is the basis for measuring performance needs to be measured, and strategic initiatives determined to realize these goals. The strategic goals and their measurements are then used to determine the targets on which to base performance appraisals. Therefore, performance is a measure that can be taken on the activities of the various value chains that exist in the company. The measurement results are then used as feedback which will provide information about the implementation of a plan where the company requires adjustments to the planning and control activities.

Organizational performance is a description of the results of the organization's work in achieving its goals which of course will be influenced by the resources owned by the organization. The resources in question can be physical such as human or non-physical resources such as regulations, information, and policies, so to better understand the factors that can affect an organization's performance. The concept of organizational performance also illustrates that every public organization provides services to the community and can measure its performance using existing performance indicators to see whether the organization has carried out its duties properly and to find out whether its objectives have been achieved or not.

\section{RESEARCH METHODS}

\section{Time and Location of Research}

A research location is a place or area where the research will be carried out. The research conducted by the author took place at PT. Arminareka Perdana. This research was conducted over 4 months, namely October 2019 to January 2020.

\section{RESEARCH DESIGN}

This study uses an explanatory analysis approach. This means that each variable presented in the hypothesis will be observed through testing the causal relationship of the independent variable to the dependent variable. The relationship between variables can be described in the form of a path analysis diagram as follows: 


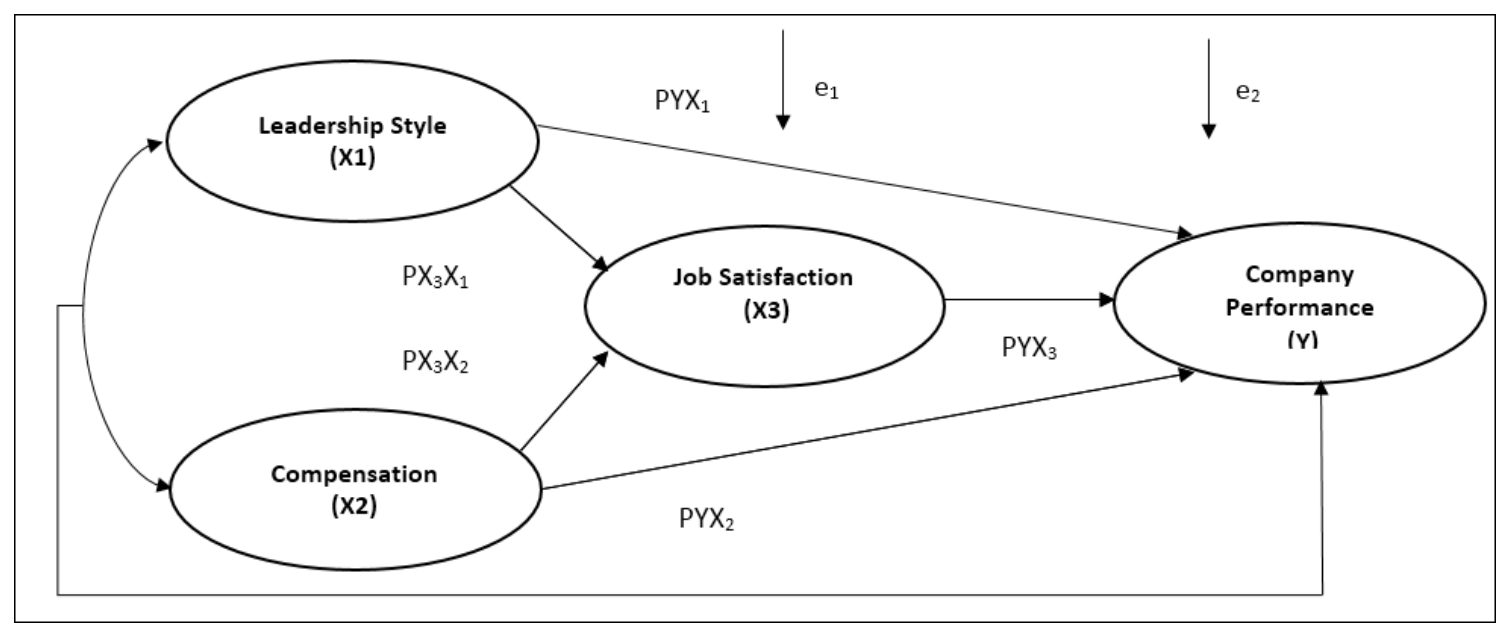

Fig-1: Overall Path Analysis

\section{Population and Sample}

The population in a study is a collection of individuals or objects which are common characteristics. Arikunto 2010: 173 explains that the population is "the whole research subject". Meanwhile, according to Sugiyono 2010: 80 population is "a generalization area consisting of objects or subjects that have certain qualities and characteristics that are determined by researchers to be studied and then draw conclusions". So from the explanation of these experts, the authors determine the population in this study are employees at PT. Arminareka Perdana numbered 85 people. The sample in this study amounted to 70 respondents.

\section{Data Analysis Technique}

Path analysis is a method of decomposing correlation into different parts to interpret an effect. In path analysis which is standardized, correlation can be broken down into structural (causal) and nonstructural (non-clausal) components based on the theory stated in the path diagram.

\section{RESEARCH RESULT}

\section{The Influence of Leadership Style on Company Performance}

The results of the analysis of the effect of leadership style on company performance partially show that the coefficient of leadership style is 0.451 . The $t$ value is 3,611 . The significant value is 0.001 . This significant value is smaller than 0.05 . This means that the leadership style variable partially affects company performance. The magnitude of the influence of leadership style on company performance is known that the value of $r$ squared is 0.161 . This means that the influence of the leadership style variable on company performance is $16.1 \%$ and the remaining $83.9 \%$ is influenced by other variables that are not included in the equation model.
The Effect of Compensation on Company Performance

The results of the analysis of the effect of compensation on company performance partially show that the compensation coefficient is 0.498 . The $t$ value is 3,990 . The significant value is 0.000 . This significant value is smaller than 0.05 . This means that the compensation variable partially affects company performance. The magnitude of the effect of compensation on company performance can be seen that the value of $r$ squared is 0.436 . This means that the influence of the compensation variable on company performance is $19 \%$ and the remaining $81 \%$ is influenced by other variables that are not included in the equation model.

\section{The Effect of Job Satisfaction on Company Performance}

The results of the analysis of the effect of job satisfaction on company performance are partially known that the compensation coefficient is 0.475 . The $t$ value is 4.799 . The significant value is 0.000 . This significant value is smaller than 0.05 . This means that the job satisfaction variable partially affects company performance. The magnitude of the influence of job satisfaction on company performance is known that the value of $r$ squared is 0.253 . This means that the influence of job satisfaction variables on company performance is $25.3 \%$ and the remaining $74.7 \%$ is influenced by other variables that are not included in the equation model.

\section{The Effect of Leadership Style on Company Performance through Job Satisfaction}

Based on the partial path analysis above, the path between leadership style and company performance through job satisfaction can be described with the following sub-structure image. 


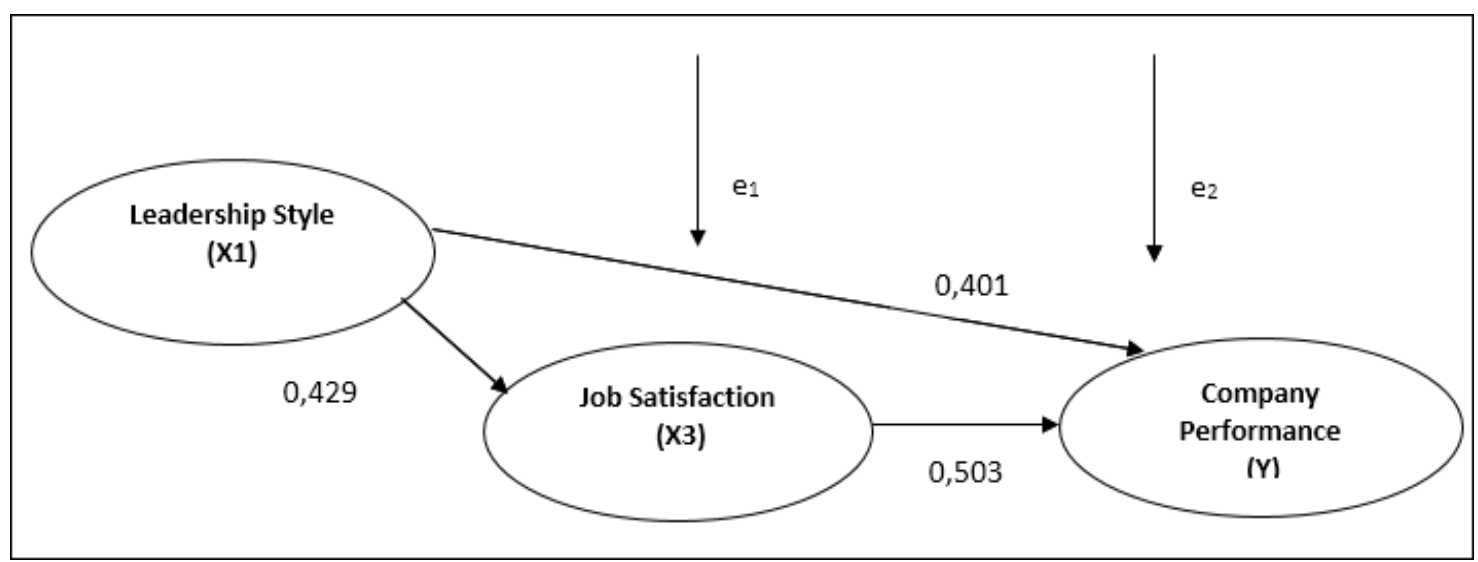

Figure 2. Path analysis of the influence of X1 on Y through X3

Based on the picture above, it can be seen that the influence of leadership style on company performance is 0.401 . The influence of leadership style on company performance through job satisfaction is $0.429 \times 0.503=0.216$. In this case, the direct effect is greater than the indirect effect, so it can be said that the job satisfaction variable is not intervening.
The Effect of Compensation on Company Performance through Job Satisfaction

Based on the partial path analysis above, path analysis can be described between compensation to company performance through job satisfaction with the sub-structure image as follows.

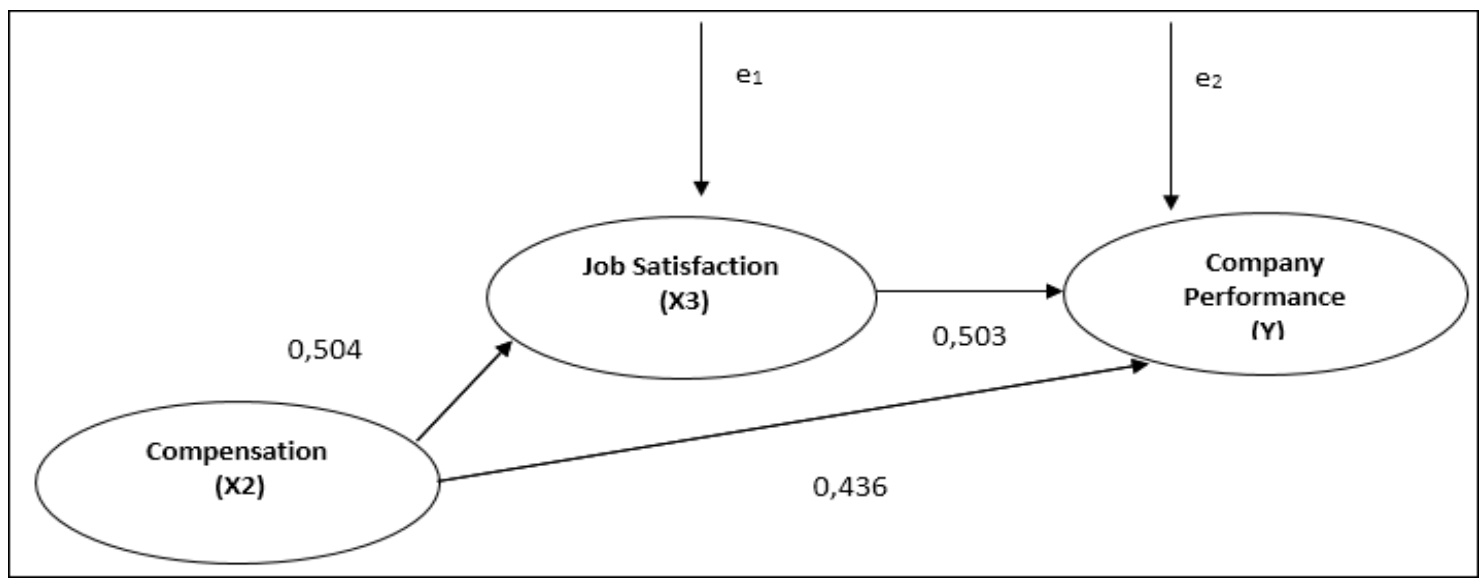

Fig-3: Path analysis of the influence of X2 on Y through X3

Based on the picture above, it can be seen that the direct effect of compensation on company performance is 0.436 . While the effect of compensation on company performance through job satisfaction is $0.504 \times 0.503=0.253$. In this case, the direct effect is greater than the indirect effect, so it can be said that the job satisfaction variable is not intervening.

\section{CONCLUSIONS AND RECOMMENDATIONS \\ Conclusion}

1. Leadership style variables affect company performance. The $\mathrm{t}$ value is 3,611. The significant value is 0.001 . This significant value is smaller than 0.05 . The value of $r$ squared is 0.161 . This means that the influence of leadership style variables on company performance is $16.1 \%$ and the rest is influenced by other variables that are not included in the equation model.
2. The compensation variable affects company performance. The $\mathrm{t}$ value is 3,990. The significant value is 0.000 . This significant value is smaller than 0.05 . the value of $r$ squared is 0.190 . This means that the influence of the compensation variable on company performance is $19 \%$ and the rest is influenced by other variables that are not included in the equation model.

3. Job satisfaction variables affect company performance. The $\mathrm{t}$ value is 4.799 and the significant value is 0.000 or less and 0.05 . The value of $r$ squared is 0.253 . This means that the influence of job satisfaction variables on company performance is $25.3 \%$ and the rest is influenced by other variables that are not included in the equation model.

4. The influence of leadership style on company performance through employee job satisfaction is 0.216 . In this case, the direct effect is greater 
than the indirect effect, so it can be said that the job satisfaction variable is not intervening.

5. While the effect of compensation on employee performance through job satisfaction is 0.253 . In this case, the direct effect is greater than the indirect effect, so it can be said that the job satisfaction variable is not intervening.

\section{Recommendations}

1. From the research results, it can be seen that the leadership style has a relatively small effect on company performance. Therefore, leaders should pay special attention to employees and be more responsible for the work and position they hold. The success of employee performance is one of the elements in improving company performance. It is hoped that by achieving a good leadership style, employee performance will be even better.

2. We recommend that the company be able to maintain the compensation that has been given and following the motivation expected by its employees to get satisfaction for its employees so that it can always make a good contribution in achieving job satisfaction so that it will have an impact on improving the company performance.

3. To improve company performance, it can be done by providing compensation for employees so that they are motivated to work and have creative work. Sensitivity is also needed to help colleagues' work as soon as possible after their work is done so that in addition to doing office work, employees also interact with fellow employees.
4. This research is still general because many other factors affect the company's performance, so the authors suggest that further researchers use the variables in this study to be examined in the future.

\section{REFERENCES}

1. Basri , A. F. M., dan Rivai, V. (2005). Performance Appraisal. PT Raja. Grafindo Persada. Jakarta.

2. Thoha, M. (2010). Kepemimpinan Dalam Manajemen. Rajawali Pers. Jakarta.

3. Hadari, N. (2003). Manajemen Sumber Daya Manusia Untuk Bisnis yang Competitif, Gajah Mada University Press, Yogyakarta.

4. Hasibuan, M. (2014). Manajemen, Dasar Pengertian dan masalah. Jakarta: Bumi Aksara.

5. Heidjrachman dan Suad Husnan, (2002), Manajemen Personalia. Edisi 5, Penerbit BPFE, Yogyakarta.

6. Herujito, Y. (2010). Dasar-dasar Manajemen. Grasindo: Jakarta.

7. Noto, A.S. (2012). Pengembangan Sumber Daya Manusia, Cetakan Ke-2, Penerbit Reneka Cipta, Jakarta.

8. Singodimedjo. (2000). Manajemen Sumber Daya Manusia. Jakarta: Bumi Aksara.

9. Wibowo. (2013). Manajemen Kinerja. Jakarta. Jakarta. Rajawali.

10. Handoko, T. Hani. (2000). Manajemen Sumber Daya Manusia. Yogyakarta: BPFE.

11. Gibson, James, L., John, M. Ivancevich., \& James, H. Donnelly. (2006). Organization BehaviorStructure-Process, $7^{\text {th }}$ Edition, Erwin Homewood, Boston. 